\title{
Contribution of Abdul Sattar Khan Niazi for Originating the Punjab Muslim Student Federation and its manifesto of "Pakistan Khilaphat Scheme"
}

\author{
Shahid Hassan Rizvi* \\ Saeed Ahmad **
}

\begin{abstract}
During the movement for Pakistan, the students played a crucial role. Particularly the efforts of students of Punjab contributed to turn the politics of Punjab, which was totally in the hand of Unionist Party and its landlords and Anglo-nabob leadership, in the favor of All India Muslim League. Mr. Abdul Sattar Khan Niazi, one of the founder members of the Punjab Muslim Students Federation drafted the manifesto of 'khilaphat-e-Pakistan' for 'The Punjab Muslim students Federation'. With this, the Federation became the vanguard of All India Muslim League in Punjab. Quaid-e-Azam Mohammad Ali Jinnah had also soft corner for the students of Punjab due to their selfless and zealous work. This article explores Mr. Niazi's efforts for establishing the Punjab Muslim Students Federation and induction of khilaphat-e-Pakistan Scheme. For this historical research, data collected is mainly through primary sources and from some secondary sources. Mostly, the data is collected through National Archives, Islamabad, National Documentation Centre, Islamabad, Dayal Singh Library, Lahore museum and through different libraries.
\end{abstract}

Key words: Abdul Sattar Khan Niazi, Punjab, Muslim Students' Federation, Khilaphat-e-Pakistan scheme.

* Professor, Department of History, Islamia University Bahawalpur

** PhD Scholar, Islamia University Bahawalpur 


\section{Introduction}

Ninetieth century witnessed far-reaching changes for the Muslims of India. They were dominate and transformed from rulers to subjects. After facing the miseries and tyrannies of the British Raj for half century, they came out of dejection and slowly and steadily started strengthening themselves under the changed circumstances and continued their struggle for attaining the rights from the colonial power. In the same time, one after other incidents of Hindu Muslim tumult during two years temporary rule of the Congress Ministries (1937-39) widened the gap between Hindu Muslim communitiesso broad that more than one thousand year history of close relationship could not unite the two communities. It changed the course of the history of united India ${ }^{1}$ and turned the Muslim's struggle for rights to struggle for independence from British Raj and the Hindu majority.

During this struggle, all members of Muslim society played a significant role but the role played by the students of Punjab is immortal. According to Mukhtar Zaman,

"The analysis shows that the Muslim students of the Punjab were the first to demand Pakistan (three years before the Lahore Resolution), were the first to mobilize the public opinion in its support, the first to hold a Special Pakistan Conference after the Lahore Resolution and were the first to have mass contact when League was a very weak organization".2

Although Many Students organizations were working during 1915 to 1930 in Punjab, but most of them were literary, their circles of influence were limited, and they had no clear program of action. ${ }^{3}$ Meanwhile a charismatic student Muhammad Abdul SattarKhan Niazi proposed to establish a pure Muslim student federation for the Muslim students of Punjab which could serve, defend and fight for the cause of Pakistan movement.

Muhammad Abdul Sattar Khan Niazi(also known as Maulana Niazi) was born on Friday, October 1, 1915 A.D (22 Zyqad, 1333 A.H) in a village "Attok Penniyala" Tehsil Isa Khel of district Mianwali. Mr. Niazi belong to very pious family so he had learned Quran at very early age and said prayers regularly including the"Tahajjud"(supererogatory prayer offered between midnight and dawn)

1 Dr. Mohammad Aarif, "Tehrik-e-Pakistan", Lahore: Progressive Publishers, Zaildar Park, Ochrah, 1994, pp.191-192

2 Mukhtar Zaman, Students' Role in Pakistan Movement, Karachi: Ma,ref Printers, 1978, p.204

3 Mukhtar Zaman, Tehrik-e-Pakistan Main Tolba ka kirdar, (Urdu), Karachi: Ahmad brothers, 1986, pp.8. http://www.senate.gov.pk/ShowMemberDetail.asp?MemberCode= $\underline{300}$ and http://www.gulemianwali.com/Politics.htm accessed 2-4-2014 
regularly in early hours of morning since he was in $6^{\text {th }}$ class. ${ }^{4}$ Then he came to Lahore got admission at Islamiah College and passed the exams of "Moballigh-eIslam" / "Maher-e-Tabligh, H.S.S.C (F.A) B.A and M.A. Abdul Sattar Khan Niazi had become a profoundorator during his studies. He was known, as "Fojdari Niazi" because, he delivered his speech with so excitement that it could be an act of offense. He fascinated his listeners and aroused them for the struggle of independence. ${ }^{5}$

During the mid-1930s, the socio-political atmosphere of Punjab was very tense. All major parties were trying to promote their influence through emotional slogans of leading isms like Communism, Nationalism, Regionalism, Socialism; Democracy and Freedom etc. In this scenario, many student associations in Punjab like All India Muslim Youth League, Punjab Students Union, Young Man Muslim Association, Anjman Nowjawanan-e-Punjab, Union of Muslim Students, Bazm-e-Tulba, Bazm-eShibly, Inter Collegiate Muslim Brother Hood, Lahore Student Union, Muslim Nationalist Youth League and National Student Federation had launched their programs.

Inter Collegiate Muslim Brother Hood was a notable Muslim students association working under the real guidance of Dr. Allama Muhammad Iqbal. It was purely nonpolitical and religious minded, intellectual association. ${ }^{6}$ The year 1936 CE was full of curiosity when Muslim league and Congress were discuss at every corner, crossing and street of Lahore. During these days, an organization "National Student Federation" a nationalist student's movement was working in Punjab University under the control of Mr. Perbodeh Kumar and Nawab Zadah Mazher Ali khan. It was influenced by Congress and propagating its agenda of Democracy, Freedom and Socialism. Its, beautiful slogan of democracy and freedom was affecting the Muslim students. Therefore, some insightful and sensitive students of Islamiah College Lahore had started thinking to launch an association, which could unite and represent the Muslim student's voice on every forum. It could also lead the Muslim students and shield them from the rising influence of Congress and Pundit Nehru's slogan of Socialism, Democracy and freedom. ${ }^{7}$ For this purpose four persons, Muhammad Abdul Sattar Khan Niazi, Mian Muhammad Shaffi (Known as Meem, Sheen-Urdu / invitation and proposal for establishing Punjab Muslim Student Federation in "Daily

4 Muhammad Sadiq Qassoori “Mojahid-e-Millat, Hayat Khidmat Taleemat”, p.55

5 Muhammad Rafiq Doger, "Chalees Chehray" 2 ${ }^{\text {nd }}$ Addition, Lahore: Milly Printers, 1977, pp.56

6 Op.Cit., Mukhtar Zaman, , pp.268

7 Baidar Malik, "Yaran-e-Makteb", vol.1, Lahore: Salman Art Press, 1986, pp.262 
Inqlab" during July and August 1936 A.D. ${ }^{8}$ According to Abdul Sattar Khan Niazi this invitation also published in various newspapers. After this appeal lot of propaganda was started by Hindu press and Jamiat Ulema-e-Hind (Pro-Congress Mullahs) such as Nazim(secretary) Jamiat-Ulema-e-Hind Moulana Ahmad Saeed Ahmad and Mr. Yusuf Maher Ali a socialist element etc.

The Congress and Pro-Congress Mullahs and Hindu Press accused Muslim students to be sectarian, shortsighted, conservative and disloyal. ${ }^{9}$ During September $1936 \mathrm{CE}$ when Punjab University Lahore reopened after summer vacation, Mr. Abdul Sattar Khan Niazi returned to Lahore and started contacting Muslim students and his friends Hameed Nizami, Mian Muhammad Shaffi and Abdul Salam Khourshid etc. for the cause of establishing the proposed student organization. Political awareness had increased a lot among the Muslim students. Meanwhile, Ibrahim Ali Chishti had published a Map of "Khilaphat-e-Pakistan" (Pakistan Caliphate) from the platform of Inter Collegiate Muslim Brother Hood. ${ }^{10}$ Some students like Nawab Zadah Mazher Ali khan (Nationalist) and Perbodeh Chander (Pro-Congress) leading "The National Student Federation" announced to hold a meeting in opposition to Quaid-e-Azam Muhammad Ali Jinnah in November, 1936 CE at Punjab University. The subject of the discussion was "Impeachment of M.A Jinnah". When Mr. Niazi read posters, he consulted with Moulana Ibrahim Ali Chishti, Mian Muhammad Shaffi, Hamid Nizami, Abdul Salam Khourshid, Abu Saeed Anwar and some other close friends and initiated a movement to counter the pro-Congress groups. Highlighting that the meeting for "Impeachment of M.A Jinnah" was shameful and a reflection of Congress's anti Islam attitude, a conspiracy of the "Hindu Brahman mind" and its "toady and dispirited Muslims puppets". English colonials and Hindu Bunya Merchants both wanted to dishonor the unblemished character of Quaid-e-Azam Muhammad Ali Jinnah by such tricks. To Niazi, Quaid's life was neat as a new pin and bright like shining sun. Yet, his opponents had conspired to ridicule him by young students without a concrete proof against him. In this way, they could spread many rumors, and create frustration and disgust in the minds of Muslim students. ${ }^{11}$ Therefore, it was very necessary to stop this plot. It was decided by Mr. Niazi, Moulana Ibrahim Ali Chishti, Mian Muhammad Shaffi, Hamid Nizami, Abdul Salam Khourshid, Abu Saeed Anwar and some other close friends to oppose it at any cost. 12 Muhammad Abdul Sattar khan Niazi described further story in an interview revealing, that: Afzal Printers, 2006,pp.44

9 Weekly, Ilham, Bahawalpur, May 28, 1987, pp. 50

10 Ibid.

11 Op.Cit. Baidar Malik, pp.261

12 Op.Cit, Ashraf Tanveer, pp-9. Weekly, Ilham, pp.51 
"After this decision, we reached University Hall before the meeting began. The Hall was full of audience. Mr. Perbodeh Kumar, Nawab-Zadah Mazher Ali khan and other Congress leaders were sitting. First, I stood up, addressed to the Stage Secretary, and raised a point of order that which courts had given you a judicial verdict of "treachery" against M.A Jinnah? Every person had right of opinion to oppose or agree to any leadership of the country. However, no one possesses the right to decide "impeachment" collectively of any leader. First, decide that who will lead the country M.A. Jinnah or M.K. Gandhi? But, the Stage Secretary rejected my point of order. After this, we all friends climbed up the stagecraft and challenged the arrangers of the ceremony that no one-sided program of impeachment could succeed and we never allowed any one to utter a contrary discussion against Quaid-e-Azam. We were ready to kill and die". 13

According to the author of "Yaran-e-Makteb" Mr. Niazi had worn his heart on his sleeve that day and he cried out to the crowed!

"Is Muhammad Ali Jinnah perfidious? Who had described it to you? Which court had given this judicial verdict against him? Whose mother's son is so plucky toutter such words against our beloved leader and left alive to go back home...? ${ }^{14}$

A jostling, outcry raised while Mr. Niazi and his friends had captured the stage and got full control of it and anyone who made an effort to climb up the stage was push down. This hand-to-hand encounter continued for some time and the stage secretary came to a compromise and changed the word impeachment according to Mr. Niazi and his group's suggestion. The stage secretary also presented a resolution "who should lead the country M.A Jinnah or M.K Gandhi". Therefore, speeches were deliver one after other in favor of both leaders. Mr. Niazi, Maulana Ibrahim Ali Chishti, Hamid Nizami, Mian Muhammad Shaffi and Abu Saeed Anwar also delivered their speeches in favor of Muhammad Ali Jinnah. The meeting ended in confusion and proved fruitless. Mr. Niazi thanked Allah for protecting the Quaid's honor and dignity from "a disloyal assemblage of opponents". 15

13 Muhammad Aslam Maitela, "Tehrik-e-Pakistan Aur Tarikh-e-Pakistan", Multan: Alkitab Graphics Printers, 2007, pp-71. Baidar Malik, "Yaran-e-Makteb", vol.1, Lahore: Salman Art Press, 1986, p.265

14 Daily Inqlab, Lahore, 6 September 1937, pp.6

15 Op.Cit, Weekly, Ilham 
Mr. Niazi had very perceptive mind, and had foresighted the image of the forthcoming days. Therefore, he categorically asserted that Muslim students must establish their organization, which could inform younger generation about their elders' heroic past and could rightly answer for such debates and accusations of the opponents. It could also provide program of action that could tackle the uprising situation. ${ }^{16}$

The proposal for establishing a Muslim student organization was a daring step, because, those days the Congress-brand Nationalism was on its peak in subcontinent which was deemed detrimental for Muslim identity and Muslim Nationalism. Any person who raised his voice for "separate Muslim nationhood" was blamed to be communalist, short sighted and bigoted.17 Although, an appeal for establishing a Muslim student federation had published in July/August 1936 CE but after the incident of "Impeachment" plot the Muslim students' minds changed intensely. Therefore, the given proposal for establishing a Muslim student organization by Mr. Abdul Sattar Khan Niazi was, attentively considered by Muslim circles for some time. Dr. Sir Muhammad Iqbal, the honorary president of Anjman Himayet-e-Islam (An association established in Lahore for promoting Islamic education and culture) was patronizing "Inter Collegiate Muslim Brotherhood". He was one of the most prominent leaders of the Muslims of India who had already proposed a separate state for the Indian Muslims in his presidential address at All India Muslim League, Allahabad session in $1930 \mathrm{CE}$. Mr. Niazi and his friends decided to consult Allama Muhammad Iqbal about establishment of Muslim Students organization.

According to the author of "Yaran-e-Makteb" Mr. Niazi revealed in a party that:

"I well remembered that it was the winter season, Dr. Sir Allama Muhammad Iqbal was sitting in couch. Hamid Nizami (late), Meem Sheen, Abdul Salam Khourshid, Abu Saeed Anwar, Ibrahim Ali Chishti (late), some other friends and I met Dr. Iqbal. He listened our conversation very keenly, when preliminary discourse ended, I represented that our attempts will not be fruitful and our viewpoint will not be considered, until we manage ourselves in shape of an organized association. Dr. Iqbal pointed to me and said that this young Niazi is presenting a proposal to establish a separate association. One of the our accompanying student said if we implemented it, we shall be defamed and accused to be sectarian, narrow minded, reactionary and antipatriotic.Dr. Muhammad Iqbal had covered

16 Op.Cit. Mukhtar Zaman, pp.265

17 Op.Cit., Muhammad Aslam Maitela 
his body with blanket, he took off his spectacles and addressed to us:

"If I suck your blood, you are entitled to dub me and snub me as a communalist, a reactionary, a narrow-minded and antinational but, I don't allow you to suck my blood I damn care for that. If, anybody dub and snub me as a communalist, a reactionary, a narrow-minded and unpatriotic, I will be the patriot of first order."

He further stressed to launch our own association asserting that "you possess all characteristics of a separate nation and I had written that:18

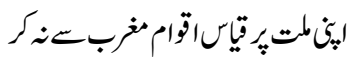

$$
\begin{aligned}
& \text { ناص تزكيبي قومر بولباثنى }
\end{aligned}
$$

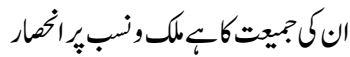

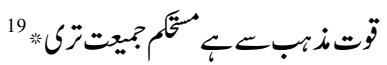

According to Muhammad Abdul Sattar Khan Niazi , Allama Iqbal excitedly raised his right hand, sat upright and said:

"I agree with Mr. Niazi, my son! Step forward, establish an association, and name it "The Punjab Muslim Student Federation". ${ }^{20}$

Dr. Iqbal further advised the students to draw up a separate program of action for the dignity and welfare of the Muslim nation for which he assured his support. Finally, it was decided to establish "The Punjab Muslim Student Federation" by December $1936 .{ }^{21}$

Op.Cit. Muhammad Sadiq Qasoori, "Mojahid-e-Millat Bahazoor Hakeem-ul-Ummat", pp-45, also Op.Cit. Weekly Ilham, pp.51. Op.Cit. Baidar Malik, pp.266

19 Syed Mushtaq Hussain Bukhari, "Jawahir-e-Iqbal", Peshawar: The Print Man Printers, 2011, pp.55

* In this stanza Dr. Iqbal advises the Muslims that foundation of Muslim nation is based upon the faith on Oneness of God and the prophet hood of Mohammad P.B.U.H. It is free from the boundaries of time space, place, cast and color. This ideology of Muslim nationalism cannot match with western nations' ideology of nationalism based upon region, country, color and language.

20 Op.Cit., Ashraf Tanveer

21 Op.Cit., Weekly Ilham, Also see Daily Inqlab Lahore, September 4, 1937, pp.6 
Mr. Niazi and his friends drafted the Manual and the Manifesto for the Federation and presented it to Dr. Iqbal for supervision and assistance. ${ }^{22} \mathrm{Dr}$. Iqbal not only liked it but also issued a powerful written statement in its favor, which was latter made a part of the manifesto of the federation. ${ }^{23} \mathrm{He}$ also promised to recommend a noble person to donate one hundred rupees for the federation. ${ }^{24}$ In the similar way, Quaide-Azam Muhammad Ali Jinnah issued a statement in the favor of the Punjab Muslim Student Federation. Thus, "The Punjab Muslim Student Federation" was establish, few weeks before the establishment of "All India Muslim Student Federation". ${ }^{25}$

The Punjab Muslim Student Federation had been working unceremoniously and membership venture continued in different colleges of Lahore for some period. According to Prof. Sharif Hussein's essay “Tehrik-e-Pakistan Main Islamiah College Lahore Ka Kirdar"(The role of Islamiah College in Pakistan movement) published in Islamiah College Lahore's magazine "The Crescent Century Number 1892-1992" wrote that "The Punjab Muslim Student Federation" was established few months before the establishment of "All India Muslim Student Federation". ${ }^{26}$ Mukhtar Zaman has supported the statement that separate Muslim student federations was already establish in Punjab and Bengal before the establishment of "All India Muslim Student Federation. ${ }^{27}$ Once Mr. Niazi, asked in a meeting about the foundational gettogether of the Punjab Muslim Student Federation, replied that he did not remember actual date but the foundation meeting was held in November 1937 CE. It was the winter season and he got admission in $3^{\text {rd }}$ year. Hamid Nizami and Nasim Hejazi were his class fellows. Sheikh Anwar-ul-Haq (Former Chief Justice of Pakistan) was present in the same meeting also corroborated the statement of Mr. Niazi that he had got admission in M.A in October 1936 at Islamiah college and in the meantime the federation was established. ${ }^{28}$ Muhammad Sadiq Qasoori who remained close to Mr. Niazi for more than 30 years until his death, wrote in his book "Mujahid-e-Millat, Hayat, Khidmat, Taleemat" that The Punjab Muslim Student Federation was founded in 1936. ${ }^{29}$ However, Sarfaraz Hussain Mirza described the inaugural date as

22 "The Crescent Century Number 1892-1992", Lahore: Islamia College, 1992, pp.73

23 Op.Cit. Mukhtar Zaman, Pp-.2, 33,104

24 Op.Cit., Baidar Malik, p.268

25 Op.Cit., "Mojahid-e-Millat, Hayat KhidmatTaleemat",p.40

26 Sarfaraz Hussain Mirza," "The Punjab Muslim Student Federation 1937-47"Islamabad: National Research Institute of Historical And Cultural Research, 1991, pp.22-41

27 Sarfaraz Hussain Mirza," "The Punjab Muslim Student Federation, An Annotated Documentary Survey,1937-47",Lahore: Research Society of Pakistan, 1978, p-fv.

28 Op.Cit., Ashraf Tanveer

29 Op.Cit., Daily Inqlab Lahore, August 12, 1937, pp.6, Mukhtar Zaman, pp.269., and also S.M. Ikram, "Modern Muslim India and the Birth of Pakistan 1858-1951" United Press, reprinted $2^{\text {nd }}$ edition, Lahore: 1977, p.280 
September 1, 1937.30 Nevertheless, later it was confirmed that the foundation of the Federation took place in late 1936 (three month earlier than the establishment of All India Muslim Student Federation) and its expansion and spreading out at Punjab level started in August/September 1937.31

According to Mr. Abdul Sattar Khan Niazi a meeting was held in January 1937 CE at Islamiah College Lahore in Habibiah Hall in which the first batch of office holders of the Punjab Muslim Student Federation was elected. ${ }^{32}$

When the Punjab Muslim Student Federation was established firmly in Islamiah and other colleges of Lahore, its growth and expansion started to nearby districts and to all over the Punjab and to other provinces. The Federation warmly welcomed by students of colleges of Punjab and other spheres of Muslims and a series of letters of support and expression of consent published in various newspapers. ${ }^{33}$ The Hindu press such as the Daily Tribune Lahore, Star of India Kolkata, Daily Milap Lahore, Daily Pertabh and even the Associated press of India crudely criticized the foundation of Muslim student organization of Punjab. Besides, the criticism of Hindu press, pro-Congress Mullahs, Jamiate Ulema-e-Hind and Communist Muslims charged the Federation as "communalist and reactionary". ${ }^{34}$ Muslim students also issued rejoinders to opponents' propaganda. Notable students of the Federation included Syed Makhdoom Abbasi, Abdul Sattar Khan Niazi, Imad-ud-Din Ahmad, Syed Fazal Hussain, Abdul-Salam Khourshid of Islamiah College Lahore, Saeed Ahmad and Syed Naseer Ahmad Shah of Government College Lahore, Zaheer-ud-din Ahmad and Ghulam Hussain B.A of F.C College Lahore, Syed Riaz Hussain and Qazi Mehmood Ahmad of Diyal Singh College Lahore, etc. ${ }^{35} \mathrm{~A}$ general meeting was held in the staff room of the Islamiah College Lahore presided by Muhammad Shafi M.A on, September 1, 1937 CE and a temporary set up of office bearers was elected: President--- Hameed Nizami; Vice President -- Mian Muhammad Shaffi; Secretary -Abdul-Salam Khourshid; Assistant Secretary -- Sheikh Imad-ud-Din and Finance secretary - Sayyed Sahid Hussain.

Sarfaraz Hussain Mirza, op.cit. Editorial, Madina (Quarterly), Bajnor, 21, September1937. Well known Congress'Muslim MLA. Iftikhar-Ud-Din, Dr. K.M Saeed criticized Muslim students due to their Separatism.

31 Ibid.

32 Daily Inqlab Lahore, August 10, 11, 12, 1937, pp.34 - 6

33 "The Punjab Muslim Student Federation1937-47",p.30

34 Op.Cit. Baidar Malik, pp-267. Well known pro-Congress Muslim MLA, Iftikhar-Ud-Din, Dr. K.M Ashraf, Mr. Yusuf Meher Ali Socialist leaders, Secretary (Nazim) Jamiat-ul-Ulema Hind, Moulana Ahmad Saeed were criticizing and blaming Muslim students due to Separatism.

35 Daily Inqlab Lahore, September 4, 1937, pp.6 
On September 29, 1937CE a general meeting of the Muslim students held in Habibiah Hall of Islamiah College Lahore, while the federation was facing hostile criticism of the opponents. This meeting was presided by Malik Barkat Ali and attended by a large number of students and teachers. The session started with the recitation of the Holy Quran by Abdul-Sattar Khan Niazi ${ }^{36}$ and thereafter messages of Quaid-e-Azam and Dr. Allama Iqbal were read out to the audience. At the end, many committees and sub-committees formed for different purposes.

Once, Moulana Niazi was telling the story of Pakistan movement in a meeting and Sheikh Anwar-ul-Haq asked Moulana Niazi why he did not take any post in the Federation's administration. Mr.Niazi replied, "If my friends had any post I conceived it, as it was mine." 37 He further, described that in the first set up, he was not interested in any administrative post of the Punjab Muslim Student Federation and he was merely a member of working committee. ${ }^{38}$

According to Syed Amjid Hussain's ${ }^{39}$ essay published in magazine "The Crescent, Century Number 1892-1992" of Islamiah College Lahore, Mr. Niazi was one of the intellectual students among Hamid Nizami (late), Abdul Salam Khourshid and Akbar Mallik etc. and he had established his prestige as a leader since the college days. ${ }^{40} \mathrm{In}$ the last days of January1938, the Lahore High Court issued a judicial decision about Masjid Shaheed Ganj's dispute. It created resentment among the Muslims. In response the students of Islamiah College, Islamiah School and other institutions organized a protest march. During the march, Mr. Abdul Sattar Khan Niazi among other students addressed the students at various places along the road expressing their resentments against the notorious verdict of the Lahore High Court. ${ }^{41}$

The year1938 CE was full of crisis for the Punjab Muslim Student Federation due to rift among the high command. Bitter words were exchange between the two factions led by President Hamid Nizami and secretary Abdul-Salam Khourshid. During this situation, Hamid Nizami the founder president resigned. It was fatal for the organization that was still in its infancy. ${ }^{42}$ During the period of confusion and conflicts in the high command, the pace of activities of the Muslim students was seriously in a feeble position.

Col. Syed Amjad Hussain was the class fellow of Muhammad Abdul Sattar khan Niazi during the days of Islamiah College Lahore.

40 Op.Cit. "The Crescent Century Number 1892-1992", pp.38

41 Op.Cit. "The Punjab Muslim Student Federation 1937-47",pp.71

42 Ibid, pp.73 
Maulana Abdul Sattar Khan Niazi revealed in a meeting that year 1937CE passed and he remained working committee member. It was beginning of $1938 \mathrm{CE}$ when the secretary of the Punjab Muslim Student Federation Abdul-Salam Khourshid met Abdul Sattar khan Niazi and insisted that the latter, because of his leadership qualities and popularity, should accept the office of the President of the Federation. ${ }^{43}$ Mr. Niazi was convinced and agreed. After some time, Abdul-Salam Khourshid changed his mind and asserted to offer the president's post to a wealthy person in order to facilitate the federation financially. Maulana Niazi opposed the intervention of wealthy persons and proposed that the members should rather mutually contribute to meet the expenditures. However, Abdul-Salam Khourshid convinced him with his effective arguments suggesting that Mr. Niazi would hold the post of Deputy President of the Federation until we select a suitable president. The latter agreed sincerely and as the Deputy President started the membership campaign in the hostels of different colleges. ${ }^{44}$ Further Maulana Niazi disclosed in an interview that as it was very difficult to enter the Government College Lahore, one night they secretly entered the "Coward Angle" from the north side of the college. "Bashir Ahmad and Ashfaq Ahmad (became Major in the Army later) of the Veterinary College cooperated with us a lot. ${ }^{45}$

Gradually the federation came out of the crisis due to the leadership and hard work of Mr. Niazi and his team. In a meeting of the working committee during May 1938, the election of the different offices of the federation was held and Federation issued some demands for Punjab Government and Punjab university authorities. These demands as published by Mr. Niazi as Deputy President of the Punjab Muslim Student Federation are as follows:

- Punjab is Muslim majority province but there are only four Muslim members out of 16 in Punjab University Syndicate. It is our strong demand to His Excellency Chancellor to include the Muslim members according to the ratio of population.

- Urdu should be adopted as medium of instruction in Punjab University.

- Muslim students must not be force to read the history of Hinduism and Buddhism. Instead of it, history of Islam, history of Arabs and history of Muslim countries should be introduce.

- Mostly History books taught in schools and Colleges of Punjab are written by prejudiced Western Orientalists. They had tried to hide our excellent past and dignity of our ancestors. So a research institute consisting of Muslim professors and scholars should be establish to prepare our history course according to trusted sources of Muslim Arab and Persian historians instead of Western Orientalists.

Op.Cit. Baidar Malik, pp.268

Ibid.

45 Ibid. 
- Today Punjab government is spending only 1, 51, 040 rupees out of 7, 11,506 on Muslim educational institutions. Rest of the grant 600,000 rupees is given to the Non-Muslim institutions. It is our strong demand to the Punjab government to distribute the grant according to the ratio of population.

- It is quite clear that Muslims of India are not ready to detach their religion from their politics, traditions and ways of livings. Therefore, any educational system, which ignored their religion, is never satisfactory for them. We strongly insist that the Punjab University manage proper religious education for young generation. ${ }^{46}$

These demands show that how the Mr. Mohammad Abdul Sattar khan Niazi was cautious about the interests of the Muslims of Punjab.

It is worth mentioning that the Congress leader ship and Nationalist were busy to create conflicting and confusing situation amongst the Muslim students since the day of formation of the Punjab Muslim Student Federation. Abdullah Butt, Akbar Malik and Muhammad Ameen of Diyal Singh College were expel due to their leanings towards the "Nationalists" and involving anti federation interests by the president of the Punjab Muslim Student Federation for one year. Muhammad Ameen was pardon later since he had submitted a written apology to the high command of the federation. ${ }^{47}$ Hindu Press published a baseless story of resignation of the secretary the Punjab Muslim Student Federation and joining the Lahore Student Union. Mischievous manners of Congress did not end here, many stories of resignation of members Like 52, again 16 members expelled, 300 members left the Punjab Muslim Student Federation and 2000 were thinking the same etc. published in Hindu Press at various times and the Punjab Muslim Student Federation issued counter statements through the press. Congressed leader Dr. Sitapal, Majlis-e-Ahrar (An association led by Conservative Ulema based on united Nationalism opposite to Muslim League's manifesto) and other nationalist's leader backed the expelled students of the Punjab Muslim Student Federation, to launch another federation "All Punjab Muslim Student Federation" parallel to the Punjab Muslim Student Federation. ${ }^{48}$

Maulana Abdul Sattar Khan Niazi reveals that Abdullah Butt, Abdullah Malik and Sardar Faizullah etc. raised up as the rival group of the Punjab Muslim Student Federation. Abdullah Butt was "Ahrari". He opposed us and launched "All Punjab Muslim Student Federation" parallel to the Punjab Muslim Student Federation. Its

46

$$
\text { 47",op.cit, }
$$

Pp.493-496

47 Op.Cit. "The Punjab Muslim Student Federation1937-47", p.41

48 Ibid. 
manifesto was based on "Nationalism".49 All Punjab Muslim Student Federation arranged a conference outside the Delhi gate, on January14, 1939 CE. It was presided and funded by pro Congress Sir Abdul Qayum Khan MLA. It was attended by Maulana Dawood Ghaznavi, Amman-Ullah Khan Niazi, Comrade Ghulam Nabi Janbaz, Maulana Hafiz-Ur-Rehman Sapoohari, Chaudhry Afzal Haq, Maulana AbdulNeman, Nazim JamiatUlema-e-Punjab; Mian Iftikhar-Ud-Din, Maulana Muhammad Hanif Nadvi, Malik Naser-Ullah Khan Aziz and Dr. Shujaa-Ullah. Education Minister Bihar Dr. Syed Mehmood could not participate due to illness and his message was read out in the meeting. Various messages were sent by notable persons, like Moulana Abul Kalam Azad, Moulana Hussain Ahmad Madni, Mufti Muhammad Kifaitullah, Moulana Ahmad Saeed Secretary Jamiat Ulema-e-Hind, Hafiz Muhammad Ibrahim , Minister U.P Government; Yaseen Noori ,Minister Mumbai Government; Dr. Zakir Hussain Principal Jamiah Milliyah College Delhi; Asif Ali, MLA., Abdul Waheed MLA., Khan Muhammad Damman MLA.,(Frontier) and Chaudhry Abdul Aziz Begowaliya. Saif-ud-Din Kitchlew presided over the next day's meeting and passed number of resolutions and during the same day election of the All Punjab Muslim Student Federation were held in Rivas Hostel, Islamiah College Lahore and Ghazi Inam-Ullah khan Niazi selected as president and Abdullah But as General Secretary. 50

According to Moulana Niazi, in this Conference these people used abusive language and condemned Quaid-e-Azam Muhammad Ali Jinnah and Dr. Iqbal. As a reaction, "we and our team up roared and created trouble in the Conference". ${ }^{51}$ In the evening session, when Moulana Zafer Ali Khan recited some verses of the Holy Quran, the Pro-Congress participants of the conference objected it for the consolation of 'Hindus and Sikhs brothers'.52Moulana Niazi further revealed that he wrote all proceedings of the conference. This was new experience for him. The report was too lengthy; Hamid Nizami told who would read it? He summarized it and a pocket size pamphlet was prepared and published with the title "Naqab Ulat Janay Kay Bad" (Exposure after lifting of the veil).

Mr. Abdul Sattar Khan Niazi wrote that:

"All the sitting persons on stage were pro-Congress and it seemed that it was the meeting of the city Congress Committee. Welcome address of the Chief of the meeting (who was from Ahrar) had advised the Muslim students to touch the feet of

49 Op.Cit. Baidar Malik, P.269

Op.Cit. "The Punjab Muslim Student Federation1937-47", pp.120. "An Annotated Documentary Survey 1937-47”, pp.158-59. "The Punjab Muslim Student Federation193747", pp.121

51 Op.Cit. Baidar Malik

52 Pamphlet "Naqab Ulet Janay Kay Bad", "The Punjab Muslim Student Federation an Annotated Documentary Survey, 1937-1947" pp.497-503 
"Gandhi" and recognize the Congress as their boss and master. The Chief Guest of the Conference a famous "Gandhi Bhaggat" (Devotee of the Gandhi) Khan Abdul Qayoum Khan said, "Muslim were not a separate nation but a sect and they could not be Muslim until they establish a united nation with Hindus...If ninety million Muslims are united still they cannot get freedom until they admit Gandhi as their leader."53

In this critical situation, Mr. Niazi united the scattered Punjab Muslim Student Federation, upgraded its manifesto and added the idea of "Khilaphat-e-Pakistan" to it. He presented demand of "Khilaphat-e-Pakistan Scheme" and its program of action. ${ }^{54}$ The federation continued its activities at full swing but once again, some misunderstandings arose between the then president Mr. Abdul Sattar Khan Niazi and Secretary Abdul-Salam Khourshid. It was a serious setback to the Federation's strength and popularity. On May 29, 1939 CE, the executive committee of the Federation gave its decision against the secretary Mr. Abdul-Salam Khourshid and expelled him for 14 years due to his misconduct. Local press propagated this controversy in the Federation.55Maulana Niazi told the story of the "disqualification" of the Secretary in his own words and said that when Abdul-Salam Khourshid wrote his resignation from his office, he called the meeting of executive body of the Federation for disciplinary action. He revealed in the meeting the decision of exclusion of Abdul-Salam Khourshid from the federation for 14 years on which Hamid Nizami was of the opinion that Mr. Khourshid should be expel for a longer period so that there would no possibility of his return in the federation. "Actually, this ruthless decision was due to his father's attachment with Unionist Party. In spite of it, Abdul-Salam Khourshid had been working with us for a long time but he possessed a bad temper so it was impossible to work for a long time with him". 56 Some other students were also expel out from the federation due to their misconduct. An inquiry committee was launch by All India Muslim Student Federation to tackle such conditions prevailing in Punjab. ${ }^{57}$

The federation was wedged in vortex but Mr. Niazi brought it out from troubles and gave line of action and a splendid period of the Punjab Muslim Student Federation ensued. Mr. Niazi and his team revised the Constitution of the Federation and launched "Khilaphat-e-Pakistan Scheme". He also wrote a letter to Nawab Zadah Liaqat Ali khan on October 17, 1939CE and sent him two pamphlets, "Revised Constitution of the federation and "Khilaphat-e-Pakistan Scheme" to the Muslim

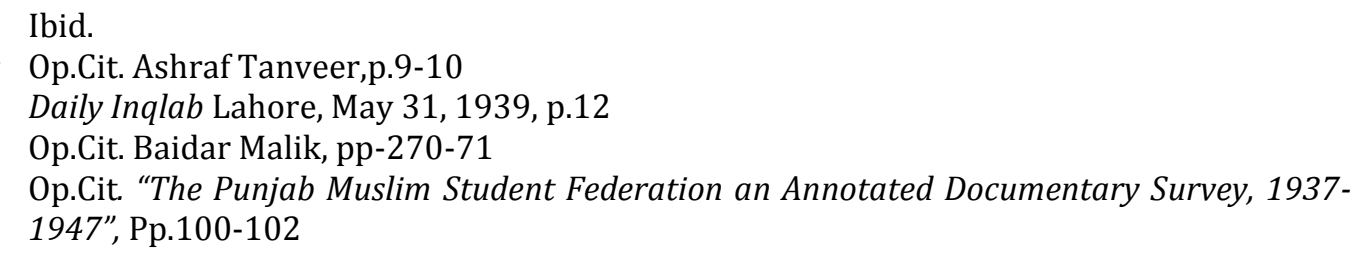


League Council. The Federation started propaganda work and published a number of pamphlets like "Nida-e- Muslimeen I, II, and III" etc. ${ }^{58}$ In spite of severe opposition and criticism of Hindus, Congress and pro-Congress Mullahs, Jamiat-Ulema-e-Hind and the socialist Muslims etc, the Federation spread almost in sixteen cities of Punjab. Students of NWFP (now K.P.K), Kashmir, Baluchistan and Sindh annexed their student organizations with the Punjab Muslim Student Federation. ${ }^{59} \mathrm{Abdul}$ Sattar Khan Niazi and his team launched the "Khilaphat-e-Pakistan Scheme" visualized by Ibrahim Ali Chishti, Mian Muhammad Shaffi and Mr. Niazi himself. The map of Khilaphat-e-Pakistanshowed Sindh, Baluchistan, NWFP and Punjab connected to Bengal and Assam through a corridor that passed through Delhi and Lucknow in U.P and reached Bengal and Assam. Once in a meeting Moulana Niazi described the flag of the proposed 'Khilaphat-e-Pakistan in following words:

"The flag of 'Khilaphat-e-Pakistan Scheme' reflects the 1300 years history of the Khilaphat and show our political aims. It has the "Ka'lemah-e-Shahadat" (Muslim creedal testimony), the Islamic teachings and program of action in few words. The four colors of the flag show the history of Khilaphat. The Black color indicates the Prophet Muhammad's flag "Rayat-ul-Aqab" and Khilaphat of Abbasids. The White color is monument of the Omayyad's. The Green color reminds us Fatimid's of Egypt and 700 years period of History and Civilization of Muslims in Spain. The Red color shows the Blood of the Martyrs and is the glimpse of the heroic deeds of the Banu Othman (The sons of Othman). The Crescent is the sign of "Khilaphat-e-Othmania". The Date Palm related to Makah "the Origin of Islam" shows our connection with Islam, in the same way our flag is hanging with "Date Palm" this tree specific for the land of Arabs. The people who have artistic taste can enjoy and understand the date palm's height, greenness, sweetness and flag on it shows its relevance with religion of peace and oneness of politics". 60

58 Ibid, pp-504-513,486-492.

59 “CRESCENT" Century Number 1892-1992" pp.74

60 Op.Cit. "The Punjab Muslim Student Federation "An Annotated Documentary Survey193747",op-cit, pp.462-485 
The 'Khilaphat-e-Pakistan Scheme' was a detaile scheme starting with the verse of Holy Quran (3:85-Al'Imran) وو من يبتغ غير الاسلام دينأ فلن يقبل منه، وهوفى الاخرة من الخسرينIt claimed that Muslims of Northern India had a birth right to their homeland and declaring themselves arch enemy of the geographical nationalism and Western democracy. All aspects and possibilities about proposed scheme were discuss such as the question of future and security of those Muslims who will remain out of the proposed scheme. The "unbelievers" living in the Pakistan Khilaphat were to be treated as Zimmis(NonMuslim citizens of an Islamic

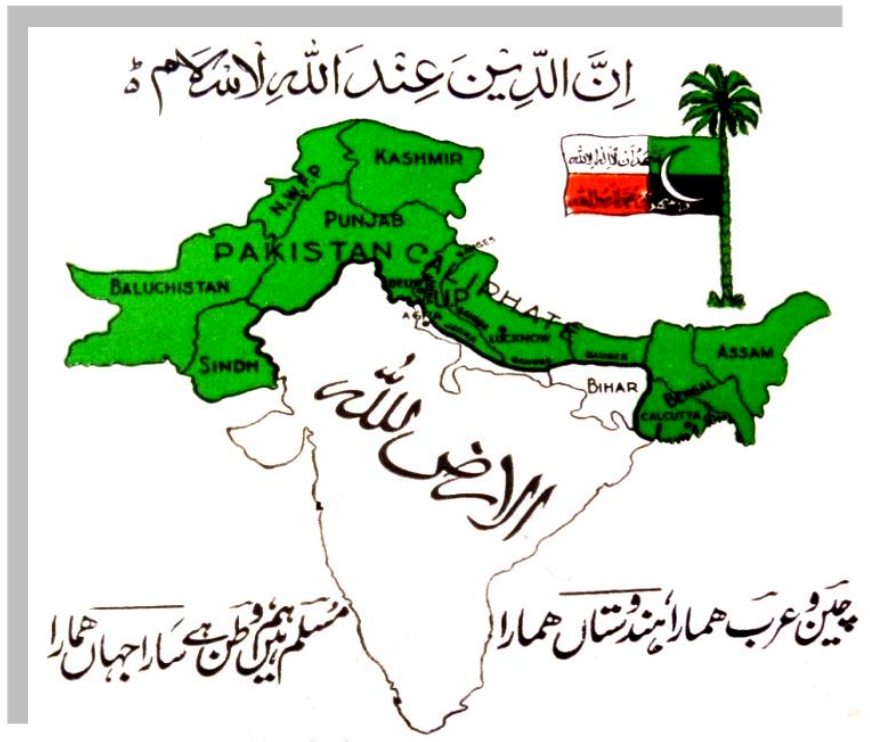
state) they would pay the Jizyah ; (Capitation-tax levied from non-Muslims for their exemption from military duty). Concept of religion, justice, government and division of India were also discuss in the scheme.62

The area for the proposed Pakistan Khilaphat covering a corridor through three provinces of India was aim to link Bengal with Pakistan and in addition, saving a fair number of Muslims of these states from Hindu majority rule. Quaid-e-Azam Muhammad Ali Jinnah had also demanded just before the actual division of India for a corridor connecting West Pakistan with East Pakistan. ${ }^{63}$

Mr. Niazi had God gifted ability of foresight enabling him to estimate the forthcoming situation. Those days Congress Ministries had started persecution of Muslims in various parts of the country particularly those areas where Muslim were in minority.

Attacks on Muslim population by some Hindu groups was an alarming situation. Mr. Niazi consulted with his team and launched military training program to prepare "Mujahidin" who could fight for the freedom and after freedom these "Mojahidin"

61 "And whoever desire something other than "Islam" as a religion, it will never be accepted from him and he will be a looser in the hereafter".

K.K Aziz "The History of Idea of Pakistan", Lahore: Vanguard Books (Pvt.) Ltd, 1987, pp.554-555

63 Daily Inqlab Lahore, July, 22, 1941, pp.3

48 
could serve as protectors and guardians of the Muslim masses. Mr. Abdul Sattar Khan Niazi took this responsibility and started working as Chief Commander of army of the Punjab Muslim Student Federation. A pamphlet "Punjab Muslim Student Federation Kay Tahet Askeri Tarbiat Ka Intezam" (Military training program for the students under the Punjab Muslim Student Federation) was issue for this purpose. ${ }^{64}$ Mr. Niazi had foreseen the changing situation. According to his statements, he had started Mujahidins' training for the future freedom fight of Pakistan. He had focused the Punjab Muslim Student Federation on one point Manifesto of Khilaphat-ePakistan. ${ }^{65}$ It is remarkable that when elders of Muslim League were presenting "Lahore Resolution" without the name of "Pakistan" then the Punjab Muslim Student Federation was holding Khilaphat-e-Pakistan Conference under the visionary leadership of Abdul Sattar khan Niazi.66 The activities of Mr. Niazi and his companions continued and created favorable conditions for the Pakistan Resolution. ${ }^{67}$

Muslim League had come to realize that there was no option left open to them to lead a peaceful, honorable and prosperous life in united India. The Congress had refused to show any leaning to hold the rising Muslim aspiration. Therefore, the demand for Muslim rights was slowly and steadily, growing toward achieving separate homeland. The announcement to hold Muslim League's annual session at Lahore on March 22-24, 1940 CE, presented an opportunity for the Muslim Students' Federation to participate for the first time in League's high-level meeting. 68 The Federation welcomed it with open arms, supported, and assisted whole-heartedly the organizers of the session. Mr. Niazi and his team was busy day and night to prepare for it and instructed all primary branches from Tehsil to District level to extend maximum support to the cause of the League. A separate wing was created to propagate the idea of the League. Another committee was constitute to make arrangements for a separate session of the Federation to be held soon after the League's annual session.

The Federation received instructions from the Provincial Muslim League leaders and responded to every request. Mian Bashir Ahmad Secretary Reception Committee of the Lahore session and Khawaja Muhammad Aslam told that entire management of the Lahore session of the League was control by the Punjab Muslim

64 Op.Cit. "The Punjab Muslim Student Federation1937-47" pp.99

65 Op.Cit. Weekly, Ilham, Bahawalpur, May 28, 1987, p. 55, "Mojahid-e-Millat, Hayat Khidmat Taleemat" p.61, and also

Muhammad Sadiq Qassoori, "Mojahid-e-Millat Aur Quaid-e-Azam", Lahore: Omair Publishers, 1994, p.9

66 Hakim Aftab Ahmad Qershi, "Karwan-E-Shouq” Lahore: Izhar Sons Printers, 1984, p.372

67 Op.Cit. "The Punjab Muslim Student Federation1937-47" p.100

68 Op.Cit. “The Punjab Muslim Student Federation1937-47" p.124 
student Federation. ${ }^{69}$ On this occasion, the Federation invited M.A Jinnah to preside a dinner function on March 21, 1940.70The leadership of the Federation decided to hold its own separate function namely Khilaphat-e-Pakistan Conference on March 24, 1940 in the Pendal (Canopy) of Muslim League at Iqbal Park Lahore. Mr. Abdul Sattar Khan Niazi got permission for it and had drafted a welcome address ${ }^{71}$ that was to be read by Mian Bashir Ahmad the secretary reception committee of Muslim League's Session. However, due to the criticism leveled in this address against the shortcomings of the Punjab Muslim League, address was not allowed for presentation even after Mr. Niazi made number of amendments. ${ }^{72}$ Finally, the Punjab Muslim Student's federation decided to hold this function separately at Habibiah Hall of Islamiah College Lahore. The Quaid could not give time due to his busy schedule in Lahore. In order to make the forthcoming conference of the Muslim league successful the Federation started a propaganda campaign by issuing statements in press and holding meetings under the title "Muselman noon ka Noujwan Tabqah Muslim League Kay Sath Hay"(Young Muslims are with Muslim League). ${ }^{73}$

On March 22, 1940CE the first day of the annual session of the All India Muslim League, a huge gathering of the Muslim students of the Punjab as well as other provinces of the India were present to lend support to the League's cause. When Quaid-e-Azam Muhammad Ali Jinnah reached Lahore Railway Station the students of the Federation warmly welcomed him and showed their splendid enthusiasm and exemplary discipline during the particular days of the session. ${ }^{74}$ The entire control of the Pindal (Canopy) was in the hands of the Punjab Muslim Student's federation. His workers had lined up the path from the entrance to the Pindal and stood with naked swords around the stage. It is worth considerable that when the great nobles of Muslim League were presenting a resolution for a separate homeland for the Muslims of India, that time Muslim students were ahead few steps and holding an exemplary function namely "Khilaphat-E-Pakistan Conference" under the visionary leadership of Abdul Sattar khan Niazi. ${ }^{75}$ It was also fortunateness of Mr. Niazi that when Premier of Bengal A.K Fazal-Ul-Haq moved the Lahore Resolution before the 105 thousand people at that time, Mr. Niazi had understood and interpreted it as the resolution of Pakistan and he had raised the slogan with his full force loudly

Mr. Niazi had vitally criticized to the Punjab Muslim League leadership. So, he was ask to made changes in it. See 72 "The Punjab Muslim Student Federation1937-47"op-sit, pp.103

73 Daily Inqlab, Lahore, March 26, 1940

74 Op.Cit. "The Punjab Muslim Student Federation1937-47", pp.104

75 Op.Cit. Weekly, Ilham, pp.55 
"Pakistan Zindah Bad" (Long Live Pakistan). ${ }^{76}$ All India Muslim League (Muslim League) leader made their speeches for demanding a free homeland for the Muslims but any person did not use the word "Pakistan" in this session. ${ }^{77}$

The Punjab Muslim Student's federation arranged "Khilaphat-E-Pakistan Conference" on March 24, 1940CE many Muslim League leaders like Serdar Ourangzaib Khan, Chaudhry Khaleeq-Uz-Zaman, Raja Sahib Mehmood Abad etc. addressed the conference. Abdul Hameed Nizami read out the welcome address and Mr. Abdul Sattar khan Niazi delivered splendid speech and said:

"Un-Islamic character is giving prominence in Punjab pointing to the building of the Punjab Assembly Hall and its Official Symbol "The Rising sun and land of rivers". I declare this is all Un-Islamic and we determined to change it."78

At the end of "Khilaphat-E-Pakistan Conference", the Punjab Muslim's Student Federation passed number of resolutions. Most of them related to the League's resolution for the establishment of an independent state for the Muslims of India. The federation recorded its strong belief in the historic Lahore Resolution. ${ }^{79}$

During June 1940CE the office of the president of the Punjab Muslim Student's federation was passed on to Mirza Abdul Hameed from Abdul Sattar khan Niazi80 On March1, 1941 Punjab Muslim Student's federation hold a "Special Pakistan Conference" and Quaid-e-Azam Muhammad Ali Jinnah was the chief Guest. He addressed the Conference and stressed the students to work for the cause of Pakistan. He also congratulated the Muslim youth of the Punjab on their determination to give thought to the Lahore Resolution. After that, the Quaid invited Abdul Sattar khan Niazi on the dais to move the

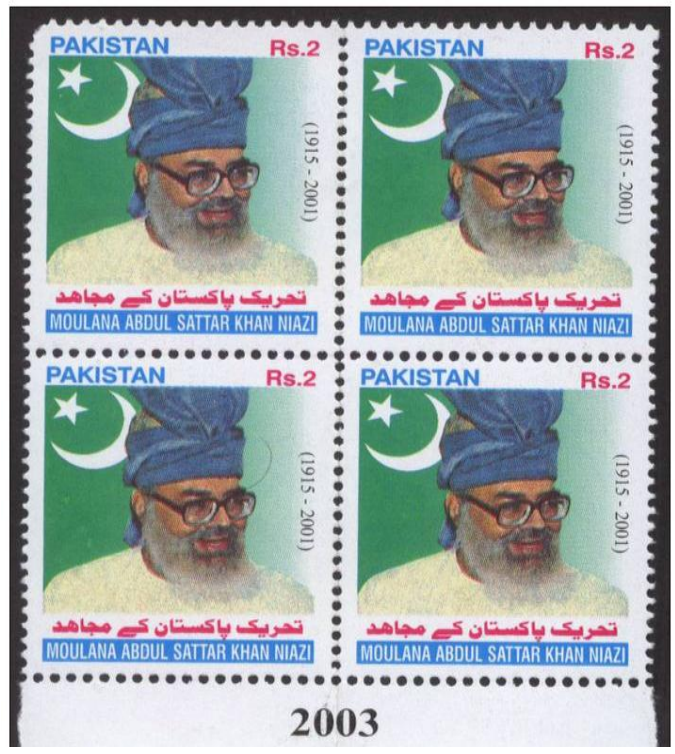

\footnotetext{
Op.Cit. Ashraf Tanveer, p.11

Op.Cit. Baidar Malik, p.279

Op.Cit. Mojahid-e-MillatAur Quaid-e-Azam",

Op.Cit. "The Punjab Muslim Student Federation 1937-47" op.cit, p.127

Ibid, pp.140-141
} 
resolution on behalf of the Punjab Muslim student federation. ${ }^{81}$ It was expression of Quaid's trust and recognition of services of Mr. Abdul Sattar Khan Niazi as student leader for Pakistan movement.

As president and founder of the Punjab Muslim Student's Federation Abdul Sattar Khan Niazi had given the Federation a strong footing and revolutionary roadmap that led to the creation of Pakistan which became its ultimate goal. Mr. Niazi continued his struggle from the platform of Punjab Muslim League.He became the Dean Faculty of Islamic Studies at Islamiah College Lahore during 1942-1946 and mobilized the student's force that had defeated anti-Muslim League elements during election of1946 in Punjab. In August 1987CE, due to his services in Pakistan movement awarded him Gold medal by Punjab government. Nation gave him the title of "Mojahid-e-Millat" (Soldier of the nation) and the government on August14, 2003 , issued a postal ticket. ${ }^{82}$

\section{CONCLUSION}

The Punjab Muslim Students' Federation took the responsibility of promoting ideology of Pakistan and proclaimed Pakistan as its goal about three years before the espousal of the Lahore resolution. Mr. Abdul Sattar Khan Niazi as the president gave firm footings to the Federation in spite of strong opposition and malicious propaganda of Nationalists, Ahraris, Khaksars, Jamiat- Ulema- Hind and Socialist elements. The Federation filled the political vacuum, created by the ineffectiveness of Muslim League in Punjab. It was the Students' Federation, which led the students of Punjab and played the primary role in the political regeneration of the Muslims in the province. That is why Muslim League became winning party during election 1945-46. In 1947, Punjab Muslim League launched civil disobedience movement for the restoration of civil liberties and students formed its vanguard and courted arrests in thousands. After the creation of Pakistan student volunteers offered support and relief to the millions of the refugees. This role was the result of guidance of the Federation. 


\section{References}

Qassoori, Muhammad Sadiq. Mojahid-e-Millat: Hayat Khidmat Taleemat. Lahore: ZiaUl-Quran Publications.2002.

Armaghn-E-Mojahid -e-Millat. Lahore: Ahsan-e-Madina Composing center, 2003.

Nazer-e-Mojahid Millat. Lahore: Zaviah Publishers, 2004.

Mojahid -e-Millat Bahazoo. Lahore: Ahsan-e-Medina Composing center, 2003.

Mojahid-e-Millat Aur Quaid-e-Azam. Lahore: Omair Publishers, 1994

Doger, Muhammad Rafiq. Chalees Chehray. Lahore: Milly Printers, 1977.

Saeed, Ahmad. Muslim India, 1857-1947. Lahore: Sidra International Communications, 1997.

Tanveer, Ashraf. Main Moulana Abdul Sattar khan Niaz. Lahore: AtishFishan Publications, 1991

Zamman, Mukhtar. Tehrik-e-Pakistan main Tolba ka kirdar. Urdu Addition, Karachi: Ahmad brothers, 1986.

Maitela, Muhammad Aslam. Tehrik-e-Pakistan Aur Tarikh-E-Pakistan. Multan: Alkitab Graphics Printers, 2007.

Malik, Baidar. Yaran-e-Makteb. vol.1, Lahore: Salman Art Press, 1986.

Mirza, Sarfaraz Hussain. The Punjab Muslim Student Federation 1937-47. Al- Islam Abad: Noor Printers, Publishers. 1991.

Ikram, S.M. Modern Muslim India and the Birth of Pakistan 1858-1951. Lahore: United Press, reprinted 2nd edition, 1977.

Aziz, K.K. The History of Idea of Pakistan. Lahore: Vanguard Books (Pvt) Ltd, 1987.

Qershi, Hakim Aftab Ahmad. Karwan-E-Shouq. Lahore: Izhar Sons Printers, 1984.

Manglori, Tufail Ahmad. Muselman noon Ka Roushan Mustaqbil. Lahore: Rasheed Printers,(n.d) 
Riyaz, Syed Hasan. Pakistan Naguzir Tha. Karachi: Sho'ba Tsnif -o-Taleef-waTerjama, Jamiah Karachi, $7^{\text {th }}$ edition, 2010.

Haider, Khawja Rizzi. Quaid-e-Azam Khatoot Kay Aa'ee'nay Main. Karachi: Publishers Nafees Academy and Printers Fazli Sons, 1985.

Sheikh, Assad Saleem .Encyclopedia Tehrik-e-Pakistan. Lahore: Zahid Bashir Printers, 1999.

Jalal, Ayesha. The Sole Spokesman. London: Cambridge University Press, 1985.

\section{Journals and Periodicals}

“CRESCENT” Century Number 1892-1992.

Civil and Military Gazette.

CRESCENT, Firogh-e-Urdu Number

Daily Inqlab Lahore.

Daily Nwai'Waqt, Lahore.

Daily Shahbaz Lahore.

Haft RozahIlham Bahawalpur. Mojahid-e-Millat addition.

Haft RozahNida'aMillat Lahore.

Mahnama, Kanz-Ul-Iman Lahore, Tehrik-e-Pakistan number.

MahnamaRaza-E-Habib Gujarat.

Manama Anwar-e- RazaKhoshab.

Paisa Akhbar (weekly

Weekly Sutlej Lahore.

\section{E Web Sites}

www.senate.gov.pk/ShowMemberDetail.asp?MemberCode $=300 \ldots$ www.pakpost.gov.pk/philately/.../moulana abdul sattar.html www.isakhel.com/maulana-abdul-sattar-khan-niazi/. 